\title{
Application of phosphate fertilization on banana hybrid 'FHIA 18'and its impact on production performance
}

\author{
Ana Carolina Batista Bolfarini ${ }^{1}$, Fernando Ferrari Putti ${ }^{2}$, Jackson Mirellys Azevedo Souza ${ }^{1}$, Marcelo de \\ Souza Silva ${ }^{1}$, Rafael Bibiano Ferreira ${ }^{1}$, Magali Leonel ${ }^{3}$, Marco Antonio Tecchio ${ }^{1}$, Sarita Leonel ${ }^{1, *}$ \\ ${ }^{1}$ Department of Horticulture, São Paulo State University (UNESP), School of Agriculture, Botucatu, São Paulo, Brazil \\ ${ }^{2}$ São Paulo State University (UNESP), School of Sciences and Engineering, Tupã, São Paulo, Brazil \\ ${ }^{3}$ São Paulo State University (UNESP), Tropical Root and Starches Center, Botucatu, São Paulo, Brazil
}

\section{*Corresponding author: sarita.leonel@unesp.br}

\section{Abstract}

FHIA 18 is a hybrid banana that could replace cultivar Prata, which is highly affected by Black Sigatoka and Panama disease. Still, there is a paucity of literature on FHIA 18 nutrient requirements, especially phosphorus. Nevertheless, we aimed to estimate the best phosphorus levels and its effect on the productive characteristics of FHIA 18 during three crop cycles in the city of São Manuel, state of São Paulo. Triple superphosphate has been given at recommended rates of 0, 20, 30, 40, 50 and $60 \mathrm{~kg} \mathrm{P}_{2} \mathrm{O}_{5}$ ha $^{-1}$ year ${ }^{-1}$ for three crop cycles that occurred in January 2014 (first cycle), August 2014 (second cycle) and June 2015 (third cycle). Results indicated that maximum fruit number per bunch was achieved at 30 and $26 \mathrm{~kg} \mathrm{P}_{2} \mathrm{O}_{5}$ ha $^{-1}$, corresponding to second and third cycle, respectively. Moreover, there was an increase in bunch mass, fruit mass, number of hands per bunch, mass and length of the fruit in the second hand, when $\mathrm{P}_{2} \mathrm{O}_{5}$ reached its maximum values from 20 to $34 \mathrm{~kg} \mathrm{P}_{2} \mathrm{O}_{5}$ ha ${ }^{-1}$ year ${ }^{-1}$, but fruits diameter decreased. Results also showed that FHIA 18 required lower level of $\mathrm{P}_{2} \mathrm{O}_{5}$ to achieve maximum yield than the recommended doses for other banana cultivars in the state of São Paulo. Therefore, this current study recommends a rate of $22 \mathrm{~kg} \mathrm{P}_{2} \mathrm{O}_{5}$ ha $^{-1}$ year ${ }^{-1}$ for FHIA 18 to reach its maximum production.

Keywords: Genetic improvement; Musa spp.; Nutrition; $\mathrm{P}_{2} \mathrm{O}_{5}$; Production. Abbreviations: P_Phosphorus.

\section{Introduction}

Banana is one of the world's most popular fruit. Thus, growing banana represents great socioeconomic importance, since many countries destined its production for export (Ghag and Ganapathi, 2017). Bananas production in Brazil has developed all agribusiness sectors, such as fertilization that enhance yield and fruit quality. Although, bananas require a lot of nutrients, due to their potential for phytomass production, they usually grow on infertile soil that are low in potassium, nitrogen and phosphorus (Nomura et al., 2017; Silva and Rodrigues, 2013).

In plant cells, there are many essential chemicals containing phosphorus (P), such as phospholipids, sugars, nucleic acids and coenzymes that are metabolic intermediate of cellular respiration. $\mathrm{P}$ also plays a role in photosynthesis, respiration, energy storage and transfer (Zhang et al., 2014). In bananas, $P$ is essential for root growth and rhizome development (Mustaffa and Kumar, 2012), as P deficiency results in low plant development and stunted bunches. Root development is granted by adequate $P$ doses, besides increasing water and nutrients uptake that contribute to fruiting (Attia et al., 2009).

It is still unclear that banana yield is influenced by phosphate fertilization; according to Liu et al. (2015) who observed a quadratic effect of increasing $P$ doses on banana yield in China. Moreover, the number of fruits and fruits per bunch increased with $\mathrm{P}_{2} \mathrm{O}_{5}$, particularly at higher doses, on 'Prata Anã' in the first cycle, under Brazilian edaphoclimatic conditions (Silva and Rodrigues, 2013). Furthermore, Bolfarini et al. (2016) verified a quadratic effect of $P$ on 'Maçã' banana in Brazil. Also, Al-Harthi and Al-Yahyai (2009) evaluated NPK fertilization on 'Williams' banana yield, obtained high bunch mass, cluster mass and fruit number per bunch at $100 \mathrm{~g} \mathrm{P}$ plant $^{-1}$ year $^{-1}$. Still, researchers suggest a need to further review the current recommendations to adapt $P$ fertilizer on banana crops.

Banana hybrid 'FHIA 18' (AAAB) is derived from cultivar 'Prata $A$ ã' ( $A A B)$, is developed by Honduras Foundation for Agricultural Research (FHIA), such hybrid stands out for better yield, 'Prata anã'- like fruits and resistance to Panama disease and Black Sigatoka (Smith et al., 2014). However, there is little information on this hybrid nutrient requirement, especially phosphorus.

Regarding to bananas, nutrients recommendations are mostly based on scientific data obtained from Cavendish subgroup (Nomura et al., 2017). Besides that, phosphorus exists in many different forms in soil, such as plant available inorganic and organic P. Phosphate is an ion with reduced mobility and its absorption is often related to root length (Attia et al., 2009), that is, root morphology may determine banana's response to phosphate fertilization. In Brazil, the predominant forms of $\mathrm{P}$ are $\mathrm{H}_{2} \mathrm{PO}_{4}{ }^{-}$and $\mathrm{HPO}_{4}{ }^{-2}$; 
thus, depends on the solution's $\mathrm{pH}$, that is, $\mathrm{pH}$ value below 7.2 prevails $\mathrm{H}_{2} \mathrm{PO}_{4}^{-}$(SHEN et al., 2011).

Banana plants do not require a large rate of phosphorus, which is one of the major macronutrients found in most fertilizers. Also, tropical soils are P-poor, as P binds to clay mineral and forms low soluble compounds (SHEN et al., 2011). In this way, many farmers are regularly using large amounts of P. In some banana plantations of Ribeirão do Sul, state of Sao Paulo, Leonel and Damatto Júnior (2007) verified high total $P$ content in soil (i.e. higher than $30 \mathrm{mg}$ $\mathrm{dm}^{-3}$ ) (RAIJ et al., 2001).

Therefore, there is a paucity of researches that have assessed the effects of phosphate fertilization on bananas, especially FHIA 18. By using suitable levels of fertilizers, the supply below and above the necessary is avoided, since adequate phosphorus supply is essential to achieve great root development; as well as nutrient and water-use efficiency. $P$ can affect liquid photosynthetic rate and its deficiency may reduce plant growth (LESSA et al., 2012). But high total $\mathrm{P}$ content in soil promotes rapid plant growth; consequently, low zinc levels in plant tissues by the dilution effect (OVA et al., 2015). Nevertheless, we aimed to estimate the best phosphorus levels and its effect on the productive characteristics of FHIA 18 during three crop cycles in the city of São Manuel, state of São Paulo.

\section{Results and discussion}

\section{The number of fruits per bunch}

Results showed low nutrients uptake by plants in first cycle, since there was no significant effect of $P$ content in soil on fruit number per bunch, with a mean of 142.05 (Fig. 1), mainly because banana presents a low demand of $P$ (Mustaffa and Kumar, 2012). The subsequent cycles presented a quadratic behavior, as the number of fruits increased to $173\left(2^{\text {nd }}\right.$ cycle) and 177 ( $3^{\text {rd }}$ cycle), with a recommended dosage of $75.3 \%$ and $64 \%$ (30.10 and $25.6 \mathrm{~kg}$ $\mathrm{P}_{2} \mathrm{O}_{5}$ ha $^{-1}$ ) (Fig. 1). By comparing to the second cycle, the third one required lower dosage, because of the great nutrient accumulation and translocation that occurred between daughter and granddaughter plants after banana clumps were well established, due to their interdependence (Kurien et al., 2006). Moreover, the decomposition of crops residues and nutrient release provided more natural $P$ availability in third cycle' plants, that is, low levels of $\mathrm{P}$ were required (Moreira and Fageria, 2009).

For the number of fruits per bunch, a gradual increase occurred from first to third cycle, except of $150 \% \mathrm{P}(60 \mathrm{~kg}$ $\mathrm{P}_{2} \mathrm{O}_{5}$ ha $^{-1}$ year $\left.{ }^{-1}\right)$, in which the means were not statistically significant, that is, $149.80\left(1^{\text {st }}\right.$ cycle $), 145.70\left(2^{\text {nd }}\right.$ cycle) and 144 ( $3^{\text {rd }}$ cycle) (Fig. 1). Still, high levels of $P$ negatively affected the hybrid FHIA 18 , as there was a reduction in the number of fruits per bunch, with regards to levels of $\mathrm{P}$ in the second and third cycle.

\section{The mass of bunches, fruits mass and number of hands per} bunch

A quadratic behavior was observed in mass of the bunches by increasing the recommended rates of $P$, these findings were corroborated by Bolfarini et al. (2016) and Liu et al. (2015). The largest mass of the bunches $(26.23 \mathrm{~kg})$ was estimated at $21.72 \mathrm{~kg} \mathrm{P}_{2} \mathrm{O}_{5}$ ha $^{-1}$ year $^{-1}$ (i.e. $54.3 \%$ of recommended dose). Also, bunch mass tended to reduce from the estimated dose (Fig. 2A). With regards to control, the estimated dose of phosphorus provided an increase in bunch mass of $5.3 \%$

Management practice and genotype also influences on the productive response, when higher levels of $P$ are used. According to Silva and Rodrigues (2013) who evaluated five doses of triple superphosphate $(0,50,100,200$ and $300 \mathrm{~g}$ of $\mathrm{P}_{2} \mathrm{O}_{5}$ ) on 'Prata Anã' (AAB) production in a clayey Red Latosol with low $P$ availability, reported a linear increase in bunch mass in function of $P$ doses. Liu et al. (2006) evaluated $P$ fertilizer on banana in China, also observed a quadratic effect in bunch mass, when increased the levels of $P$ that were much higher than those evaluated in this current study. Bolfarini et al. (2016) observed on the production of 'Maçã' banana ( $A A B)$ that the largest bunch mass was achieved with $34 \mathrm{~kg} \mathrm{P}_{2} \mathrm{O}_{5} \mathrm{ha}^{-1}$ in the first cycle. Furthermore, the use of low doses of fertilizers becomes financially interesting, as it cuts final production costs.

For FHIA 18, the low $P$ requirement may be related to initial $P$ availability in soil $\left(16 \mathrm{mg} \mathrm{dm}^{-3}\right)$, which is about plant's sufficiency, besides the inheritance of root growth on this cultivar, since phosphate is an ion with reduced mobility, then absorption is often related to root length (Attia et al., 2009).

Rachis mass was not influenced by $\mathrm{P}$ doses and production cycles, with a mean value of $2.14 \mathrm{~kg}$; therefore, an expected result, since fruit and bunch mass are directly related and presented similar response in function of $\mathrm{P}_{2} \mathrm{O}_{5}$. Then, the maximum response for fruit mass $(24.01 \mathrm{~kg})$ was reached at $54.8 \%$ recommended dose (Fig. $2 \mathrm{~B}$ ).

There is a low need of $P$ when growing bananas, but it must be ensured, as $P$ is essential for rhizome development and root formation, besides playing a vital role in plants overall development and flowering (Mustaffa and Kumar, 2012). AlHarthi and Al-Yahya (2009) evaluated the production of banana cultivar 'Williams' (AAA) in sandy soil, submitted to four $\mathrm{N}$ (urea) combinations, $\mathrm{P}_{2} \mathrm{O}_{5}$ (triple superphosphate) and $\mathrm{K}_{2} \mathrm{O}$ (potassium chloride): 0-0-0; 300-50-250; 600-100500 and $900-150-750$ g plant $^{-1}$ year $^{-1}$, observed that $100 \mathrm{~g}$ $\mathrm{P}_{2} \mathrm{O}_{5}$ plant $^{-1}$ year $^{-1}$ increased in fruit mass.

The number of hands per bunch increased in a quadratic form with $P$ rates, as the maximum value ( 10 hands per bunch) was obtained at $84.4 \%$ of the recommended dose $\left(33.60 \mathrm{~kg} \mathrm{P}_{2} \mathrm{O}_{5}\right.$ ha $^{-1}$ year $\left.{ }^{-1}\right)$. Although, this estimated dose promoted a $6.3 \%$ increase in number of hands per bunch, when there was no P content in soil (Fig. 2C). The increase in mass of the fruits and bunches to optimum $P$ levels can be associated with the increase in the number of fruits and hands per bunch, which may be related to adequate $P$ availability. Phosphorus is essential for photoassimilate, storage and transfer processes in plant tissues (Zhang et al., 2014). However, $P$ in excess promotes rapid plant growth; consequently, reducing yield by decreasing zinc absorption (Ova et al., 2015). These findings are corroborated by Attia et al. (2009) who found that P (BSP) and phosphorus (25\%, $50 \%$ and $\left.75 \% \mathrm{P}_{2} \mathrm{O}_{5}\right)$ promoted a greater number of hands per bunch on banana 'Maghrabi' production compared to $75 \% \mathrm{P}_{2} \mathrm{O}_{5}$, but also bacteria was associated with $25 \% \mathrm{P}_{2} \mathrm{O}_{5}$.

\section{The mass, length and diameter in fruits of the second hand}

$P$ levels promoted a quadratic increase in fruit mass and length of the second hand, as maximum function was reached at 19.74 and $26.92 \mathrm{~kg} \mathrm{P}_{2} \mathrm{O}_{5}$ ha $^{-1}$ year $^{-1}(49.4 \%$ and $67.1 \%$ of the recommended dose), respectively. Thus, 
Table 1. Means of bunch mass (BM), fruit mass (FM), number of hands per bunch (NHB), mass of the second hand (2BM), number of fruit number in second hands (FN 2ㅇ) and fruit length (FL) of bananas hybrid 'FHIA 18' (AAAB) in first, second and third production cycle, São Manuel, state of São Paulo.

\begin{tabular}{llllll}
\hline Cycles & $\begin{array}{l}\text { BM } \\
(\mathrm{kg})\end{array}$ & $\begin{array}{l}\text { FM } \\
(\mathrm{kg})\end{array}$ & NHB & $\begin{array}{l}\text { 20BM } \\
(\mathrm{kg})\end{array}$ & $\begin{array}{l}\text { FN 2oP } \\
(\mathrm{kg})\end{array}$ \\
\hline First cycle & $22.32 \mathrm{~b}$ & $20.15 \mathrm{~b}$ & $9.54 \mathrm{~b}$ & $2.33 \mathrm{~b}$ & $16.51 \mathrm{~b}$ \\
Second cycle & $24.78 \mathrm{a}$ & $22.66 \mathrm{a}$ & $9.82 \mathrm{ab}$ & $2.77 \mathrm{a}$ & $15.90 \mathrm{~b}$ \\
Third cycle & $25.96 \mathrm{a}$ & $23.85 \mathrm{a}$ & $10.18 \mathrm{a}$ & $2.59 \mathrm{a}$ & $18.23 \mathrm{a}$ \\
\hline DMS & 1.92 & 1.77 & 0.41 & 0.25 & $18.23 \mathrm{a}$ \\
\hline
\end{tabular}

Means followed by the same lowercase letters are not significantly different according to Tukey test $(p \leq 0.05)$.

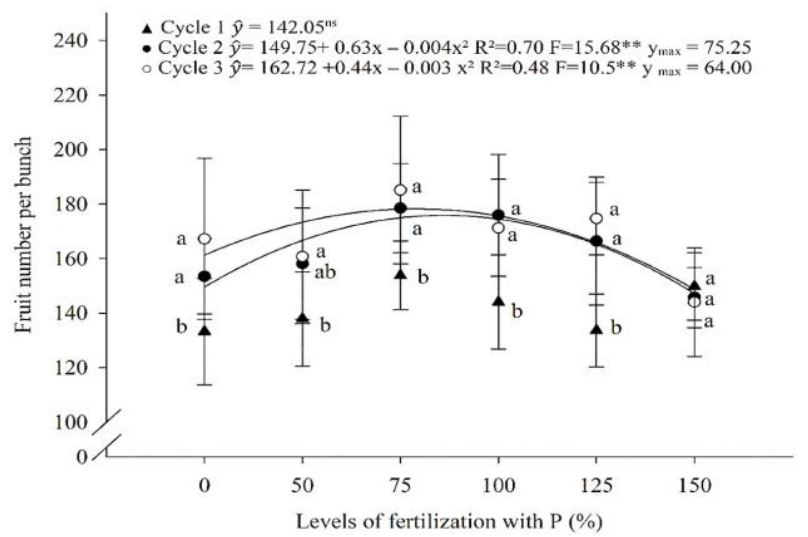

Fig 1. Fruit number per bunch of banana hybrid ' $F H I A$ 18' (AAAB) in function of phosphate fertilization over three cycles. FCA/UNESP, São Manuel, state of São Paulo, 2018. Equal letters among cycles do not differ by Tukey test at the 5\% probability.

Table 2. Chemical characteristics and macronutrient and micronutrient contents of the soil of the experimental area before the planting of the 'FHIA 18' banana hybrid in São Manuel.

\begin{tabular}{|c|c|c|c|c|c|c|c|c|c|c|c|c|c|c|c|c|}
\hline \multirow{2}{*}{$\begin{array}{l}\text { Sample } \\
\text { (cm) }\end{array}$} & \multirow{2}{*}{$\begin{array}{l}\mathrm{pH} \\
\mathrm{CaCl}_{2}\end{array}$} & \multirow{2}{*}{$\begin{array}{l}\text { M.O. } \\
\text { g. } \mathrm{dm}^{-3}\end{array}$} & \multirow{2}{*}{$\begin{array}{l}\mathrm{P} \quad \text { resin } \\
\mathrm{mg} \cdot \mathrm{dm}^{-3}\end{array}$} & $\mathrm{H}+\mathrm{Al}$ & K & $\mathrm{Ca}$ & $\mathrm{Mg}$ & SB & \multirow{2}{*}{ CTC } & \multirow{2}{*}{ V\% } & $S$ & $\mathrm{~B}$ & $\mathrm{Cu}$ & $\mathrm{Fe}$ & $\mathrm{Mn}$ & $\mathrm{Zn}$ \\
\hline & & & & \multicolumn{5}{|c|}{---mmolc dm ${ }^{-3}$} & & & \multicolumn{6}{|c|}{-----mg dm ${ }^{-3}----$} \\
\hline $0-20$ & 5.5 & 12 & 16 & 15 & 1.0 & 13 & 5.0 & 19 & 34 & 57 & 1.0 & 0.3 & 0.86 & 20 & 13 & 1.4 \\
\hline
\end{tabular}
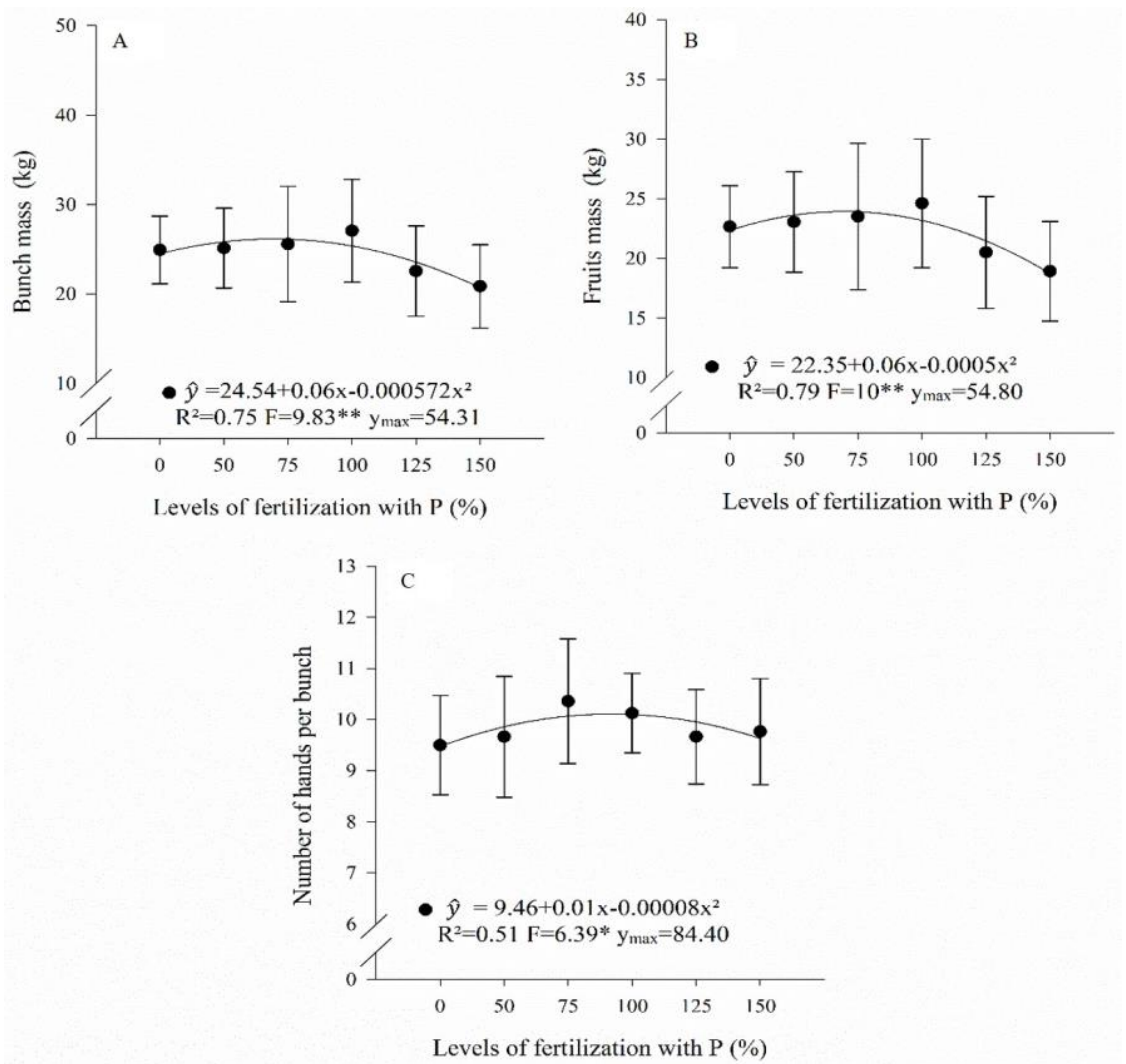

Fig 2. Bunch mass (A), Fruits mass (B) and number of hands per bunch (C) of banana hybrid 'FHIA 18' (AAAB) in function of phosphate fertilization. FCA/UNESP, São Manuel, state of São Paulo, 2018. 

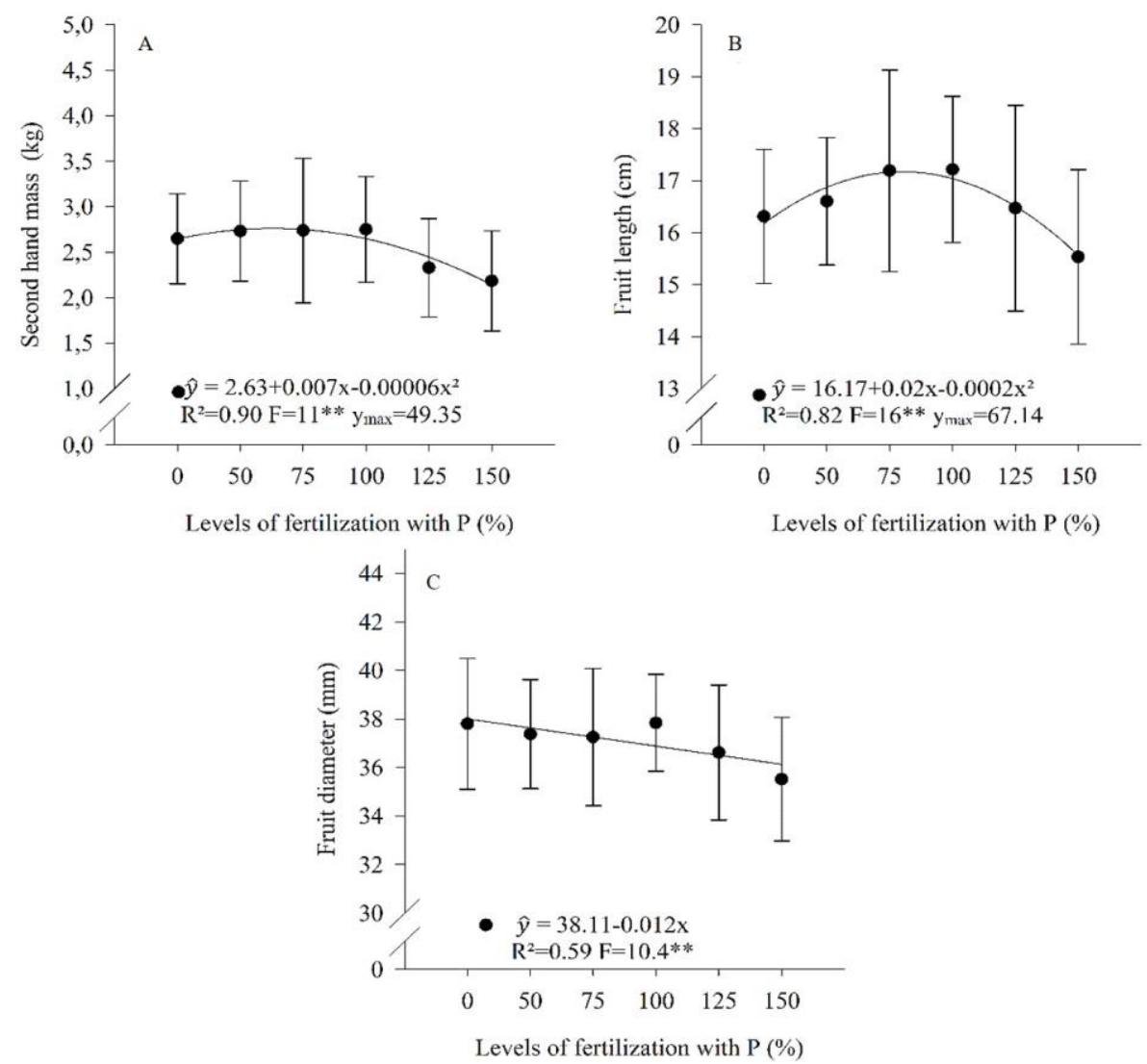

Fig 3. Mass (A), length (B) and diameter (C) of the bunch from the second hand of banana hybrid 'FHIA 18' (AAAB) in function of phosphate fertilization. FCA/UNESP, São Manuel, São Paulo state, 2018.

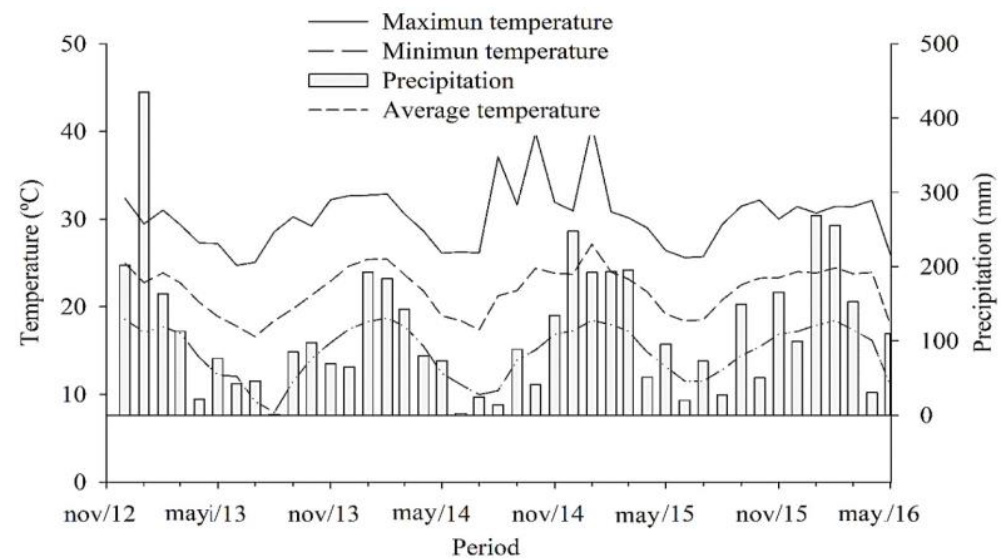

Fig 4. Monthly average temperature and precipitation in the city of São Manuel, state of São Paulo, from November 2012 to January 2016.

corresponding to an increase of $4.9 \%$ in fruit mass of the second hand and $5.0 \%$ in fruit length compared to control (Fig. $3 \mathrm{~A}$ and $3 \mathrm{~B}$ ). However, $\mathrm{P}_{2} \mathrm{O}_{5}$ did not influence on the number of fruits per bunch in the second hand, that is, this variable is conditioned to genetic factor and weather conditions, as climate changed over the cycles. Moreover, the productive components in fruits of second hand were the only one to be influenced by production cycles.

For fruit mass and length of the second hand, the increase until the maximum estimated dose can be related to $P$ activity in protein synthesis and cellular elongation (Zhang et al., 2014). Besides $P$ enables root and tree growth, i.e. higher yield. According to Ramaswamy (1974), there is an increase in fruit length and diameter up to the $60 \mathrm{~g} \mathrm{P}_{2} \mathrm{O}_{5}$ plant $^{-1}$, which is similar to that found by Navaneethakrishnan et al. (2013), who evaluated the influence of $N$ and $P$ on cultivar
'Grand Naine' (AAA) in northern India, reported a significant difference between two levels of $\mathrm{P}\left(60\right.$ and $90 \mathrm{~g} \mathrm{P}_{2} \mathrm{O}_{5}$ per plant), showed that the lower $\mathrm{P}$ dose resulted in a larger bunch mass. High $P$ content in soils can affect other nutrients availability, especially zinc, which impairs plant development (Novais et al., 2016), and as a consequence yield may be reduced. Furthermore, banana trees produce small fruits under low zinc availability (Silva and Rodrigues, 2013).

For fruit diameter, FHIA 18 presented lower phosphorus requirements compared to mass and length of the fruits from the second hand, as a linear decrease occurred in function of phosphate fertilization (Fig. 3C). Such outcome may be related to the inhibition of starch synthesis by high concentrations of inorganic phosphorus that impairs ADPGlucose Pyrophosphorylase action, a key enzyme of starch 
synthesis in amyloplasts (Taiz et al., 2017). In plant tissue, low phosphorus content promotes the expression of genes involved in starch synthesis, and consequently the accumulation of carbohydrates (Zhao et al., 2014).

The quadratic effect of phosphate fertilization on most productive traits is consistent with phosphorus content in leaf. The highest value of $P$ in leaves $\left(1.63 \mathrm{~g} \mathrm{~kg}^{-1}\right)$ was obtained with $89.7 \%$ of recommended dose. In relation to production cycles, high $\mathrm{P}$ content was observed in second $\left(1.63 \mathrm{~g} \mathrm{~kg}^{-1}\right)$ and third cycle $\left(1.64 \mathrm{~g} \mathrm{~kg}^{-1}\right)$; these levels were within sufficiency range, according to Silva and Rodrigues (2013). After successive applications of phosphate fertilizer, the mean value of $P$ available in soil was of $56.88 \mathrm{mg} \mathrm{dm}^{-3}$ with the highest $\mathrm{P}_{2} \mathrm{O}_{5}$ dose at the end of the experiment.

\section{Isolated effect on production cycles}

When production cycles were evaluated, there was practically significant effect on all the productive traits, except for rachis mass and the middle finger diameter of the second hand, which can be explained by plants vigorousity, productive potential and weather conditions that changed over the cycles. The mean mass of bunches, fruits, bunches of the second hand, fruit number and fruit length of the second hand over second and third cycle were higher than first production cycle. However, there was no statistically significant difference between values obtained in first and second cycles for number of hands per bunch (Table $1)$.

These findings are corroborated by Silva et al. (2002), who evaluated banana genotypes during four production cycles in the city of Rio das Almas, state of Bahia; reported a stable FHIA 18 production from second cycle on, with a mean mass of $21.4 \mathrm{~kg}$, which was obtained in third production cycle.

In most genotypes, productive traits can increase from first to the second cycle, as first production cycle is not considered the most appropriate moment to assess banana production (Silva et al., 2002; Silva and Rodrigues, 2013). This increase in production is probably due to change in vigor and productive potential of banana trees over cycle's course. According to Nomura et al. (2017), banana plants have better nutritional conditions in the second cycle than the first one, because the connection between rhizome of the mother and daughter plants, as it acts as an 'umbilical cord', where sap and hormones can be exchanged within the second crop cycle on. Therefore, the premise that banana trees of the same family are interdependent justifies the gradual increase in plants vigor and production throughout cycles (Silva and Rodrigues, 2013; Kurien et al., 2006). Therefore, it is recommended that harvested plants remain into field for at least one month to transfer these nutrients to the clump (Nomura et al., 2017).

During floral differentiation stage, genetics, growth cycle, temperature, vigor and management practice can compromise fruit number and number of hands per bunch in banana plantations (Robinson and Gálan-Saúco, 2011; Nomura et al., 2017).

By considering climate data (Fig. 4), it is possible to observe that the highest precipitations were recorded during productive phases of both second (September 2014 to February 2015) and third cycle (July 2015 to January 2016), when compared to first cycle (December 2013 to April 2014), which may have also contributed to the higher productive income in second and third cycle in relation to first. In plants, low water availability impairs fruit-filling phase (Turner et al., 2007), such physiological event involves carbohydrates translocation within plants that depend on water content. In addition, cell expansion and/or elongation processes that occur during fruiting phase also depend on water availability in plants (Taiz et al., 2017).

\section{Materials and methods}

\section{Area location and characterization}

This study was conducted at Sao Manuel Experimental Farm in the School of Agriculture (FCA-UNESP). This farm is in the city of São Manuel, state of São Paulo $\left(22^{\circ} 44^{\prime} 28^{\prime \prime S}\right.$ $\left.48^{\circ} 34^{\prime} 37^{\prime \prime} \mathrm{W}\right)$, at an altitude of $740 \mathrm{~m}$, and the farm's soil is classified as Red Latosol. The climate is humid subtropical $(C f a)$ that is, temperate hot (mesothermic), with concentrated rains from November to April (summer) and mean annual precipitation of $1376.70 \mathrm{~mm}$; the mean temperature of the warmest month in the city exceeds $22^{\circ} \mathrm{C}$ (Cunha and Martins, 2009).

The current experiment lasted three production cycles. The first production cycle occurred from November 2012 to April 2014; the second from August 2014 to February 2015; and the third from June 2015 to January 2016. Therefore, the first production cycle corresponded to the period between planting and harvesting, while the second and third cycle was between inflorescence emission and harvesting. During the whole experiment course, all data related to precipitation $(\mathrm{mm})$, maximum, mean and minimum temperatures $(\stackrel{\circ}{ })$ ) were collected through CIIAGRO system (CIIAGRO, 2018), as presented in Figure 4.

Prior to experiment, soil samples were collected in subplots at a $0-20 \mathrm{~cm}$ soil depth to determine soil chemical analyses (Table 2); therefore, based on that and the recommendations for banana crop, the experimental area was previously prepared with plowing, sorting and liming (Teixeira et al., 2014).

The micropropagation of FHIA 18 banana seedlings, which were at the age of two months, were carried out on November 8, 2012, with a spacing between lines of 4 meters and a spacing of plants of 2.5 meters, that is, 1000 plants ha ${ }^{-1}$. Also, weed control, tiller thinning, removal of dry and diseased leaves, control of crop pests and diseases, removal of banana heart and pistils, and harvesting were performed accordingly to guidelines and standards for banana crops (Teixeira et al., 2014).

\section{Description of the banana hybrid cultivar FHIA 18}

Being developed by the Honduran Agricultural Research Foundation (FHIA), it is a tetraploid hybrid (AAAB) originated from plants of the cultivar 'Prata Anã' (AAB). It has fruits like those of Prata in, besides fruits are easy-to-fall. FHIA 18 presents high yields, such as bunches up to $40 \mathrm{~kg}$ and 10 hands, and resistance to Panama disease and Black Sigatoka, but is susceptible to bacterial wilt-diseased (Smith et al., 2014)

\section{Phosphate fertilizer and nutrient management}

P fertilizer (100\%) was standardized accordingly to soil chemical analyzes and expected yield of less than $20 \mathrm{t} \mathrm{ha}^{-1}$ (Teixeira et al., 2014). Therefore, the levels of $P$ fertilizer were $\mathrm{D} 1=$ no application (control); $\mathrm{D} 2=50 \%$ of $\mathrm{P}$ standard recommendation $\left(20 \mathrm{~kg} \mathrm{P}_{2} \mathrm{O}_{5}\right.$ ha $^{-1}$ year $\left.{ }^{-1}\right) ; \mathrm{D} 3=75 \%$ of $\mathrm{P}$ 
standard recommendation (30 kg $\mathrm{P}_{2} \mathrm{O}_{5}$ ha $^{-1}$ year $^{-1}$ ); D4 = $100 \%$ of $\mathrm{P}$ standard recommendation ( $40 \mathrm{~kg} \mathrm{P}_{2} \mathrm{O}_{5}$ ha $^{-1}$ year $\left.^{-1}\right)$; $\mathrm{D} 5=125 \%$ of $\mathrm{P}$ standard recommendation $\left(50 \mathrm{~kg} \mathrm{P}_{2} \mathrm{O}_{5} \mathrm{ha}^{-1}\right.$ year $^{-1}$ ); and D6 $=150 \%$ of $P$ standard recommendation $(60 \mathrm{~kg}$ $\mathrm{P}_{2} \mathrm{O}_{5}$ ha $^{-1}$ year $^{-1}$ ). Furthermore, triple superphosphate $(46 \%$ $\mathrm{P}_{2} \mathrm{O}_{5}$ ) was used as the source of phosphorus.

The application of phosphate fertilizer followed the recommendation proposed by Teixeira et al. (2014), that is, half-dose was locally applied in planting pits; and the other half was applied in a circle of $100 \mathrm{~cm}$ diameter around plants at 80 days after planting.

In the first, second and third production cycles, $\mathrm{P}_{2} \mathrm{O}_{5}$ doses were applied and evaluations percentage were kept $(0,50$, $75,100,125$ and $150 \%$ of recommended dose), being the applications realized in the form of semicircle $(100 \mathrm{~cm}$ radius) in front of the youngest shoot. These applications occurred in January 2014, August 2014 and June 2015 for the first, second and third production cycles, respectively. Furthermore, the application period corresponded to the emission of the inflorescence in each cycle.

Plants were conducted in a rainfed system and clump formation. Complementary nutritional management was carried out, based on soil analyzes and guidelines for banana crop proposed by Teixeira et al. (2014). The applications of $600 \mathrm{~g}$ of ammonium sulphate and $550 \mathrm{~g}$ of potassium chloride occurred in a period from December 2012 to June 2013, when banana clumps were formed. Fertilizers were applied in a whole circle of $100 \mathrm{~cm}$ diameter around plants. Moreover, production fertilizations were applied in a halfcircle of $100 \mathrm{~cm}$ radius, right in front of the youngest shoots, that is, $267 \mathrm{~g}$ of urea and $217 \mathrm{~g}$ of potassium chloride per clump, split into first and second cycle; $422 \mathrm{~g}$ of urea and $250 \mathrm{~g}$ of potassium chloride; and $422 \mathrm{~g}$ of urea and $350 \mathrm{~g}$ of potassium chloride throughout third cycle. Also, $10 \mathrm{~g}$ of boric acid, $25 \mathrm{~g}$ of zinc sulphate and $2 \mathrm{~kg}$ of Provaso organic compound were applied in all clumps over the cycles.

\section{Harvest and production performance}

Banana bunches were harvested when fruits of the second hand presented a diameter of at least $36 \mathrm{~mm}$, and the following production variables were evaluated: bunch mass $(\mathrm{kg})$, rachis mass $(\mathrm{kg})$, fruit mass $(\mathrm{kg})$, fruit number per bunch and number of hands per bunch. For bunches of the second hand, it was determined total mass ( $\mathrm{kg})$, number of fruits, length $(\mathrm{cm})$ and diameter $(\mathrm{mm})$ of the five middle fruits. The mass of the bunch was obtained by weighing bunch, rachis and fruits, obtained by the difference between the mass of bunch and rachis and expressed in kilograms (kg).

\section{Experimental design and statistical analysis}

A completely randomized factorial design, where 6 levels of $\mathrm{P}$ and 3 production cycles were assigned to the treatments, with ten replicates. Thus, main plot was composed of phosphorus levels, followed by three production cycles in subplots.

Data were submitted to analysis of variance and, when significant, means of quantitative data were submitted to regression analysis at $5 \%$ probability $(p<0.05)$. Tukey test ( $p$ $<0.05$ ) was used for qualitative data analysis. Variance and regression analysis were performed by SISVAR - Computer Statistical Analysis System (Ferreira, 2011). The models of regression curves were adjusted by SigmaPlot version 12.5 .
It does seem feasible to conclude that FHIA 18 requires $22 \mathrm{~kg}$ $\mathrm{ha}^{-1}$ of $\mathrm{P}_{2} \mathrm{O}_{5}$ year ${ }^{-1}$ to reach maximum production in the edaphoclimatic conditions in the city of Sao Manuel. Still, this dose is lower than the guidelines proposed by banana crops in the state of São Paulo. Furthermore, when productive traits were enhanced in first cycle, the subsequent cycles reached maximum productive yield.

\section{Acknowledgments}

We acknowledge to CNPq (\#304455/2017-2) and CAPES for financial support.

\section{References}

Al-Harthi K, Al-Yahyai R (2009) Effect of NPK fertilizer on growth and yield of banana in northern Oman. J Hortic For. 1: $160-167$

Attia M, Ahmed MA, El-Sonbaty MR (2009) Use of biotechnologies to increase growth, productivity and fruit quality of 'Maghrabi' banana under different rates of phosphorus. World J Agric Sci. 5: 211-220.

Bolfarini ACB, Leonel, S, Leonel $M$, Tecchio MA, Silva MS, Souza, JMA (2016) Growth, yield and fruit quality of 'Maçã' banana under different rates of phosphorus fertilization. Aust J Crop Sci. 10: 1368-1374.

CIIAGRO. Centro Integrado de Informações Agrometeorológicas, 2017. Available in: $<$ http://www.ciiagro.sp.gov.br>, accessed in 2017 November.

Cunha AR, Martins D (2009) Climatic classification for the districts of Botucatu and São Manuel, SP. Irriga. 14: 1-11.

Ferreira DF (2011) Sisvar: A computer statistical analysis system. Cienc Agrotec. 35: 1039-1042.

Ghag SB, Ganapathi TR (2017) Genetically modified bananas: To mitigate food security concerns. Sci Hortic. 214: 91-98.

Kurien S, Kumar PS, Kamalam NV, Wahid PA (2006) Intermat and intramat competition in banana studied using 32P. Fruits. 61: 225-235.

Leonel S, Damatto Junior ER (2007) Caracterização das áreas de cultivo da bananeira 'Maçã' na região de Ribeirão do Sul-SP. Cienc Agrotec. 31: 958-965.

Lessa LS, Ledo CAS, Amorim EP, Silva SO (2012) Características vegetativas e seus efeitos sobre a produção de bananeira em três ciclos. Rev Bras Frutic. 34: 10981104.

Liu $Y$, Jing T, Tang F, Zang $X$, Zheng $W$, Cao H, Ju J, Wang B, Li C (2015) Studies on the fertilization effect and optimal fertilizing amount of Brazil banana based on "3414" field trials. Agric Sci Tech. 16: 1950-1954.

Malavolta E, Vitti GC, Oliveira SA (1997) Assessment of nutritional status of plants: principles and applications. 2 edh. 319 p.

Martin-Prével P (1984) Bananier. In: Martinprével P, Gagnard J, Gautier P (Eds) L'analyse végétale dans le contrôle de l'alimentation des plantes tempérées et tropicales. Lavoisier, Paris.

Moreira A, Fageria NK (2009) Repartition and remobilization of nutrients in banana trees. Rev Bras Frutic. 31: 574-581.

Mustaffa MM, Kumar V (2012) Banana production and productivity enhancement through spatial, water and nutrient management. J Hortl Sci. 7: 1-28. 
Navaneethakrishnan KS, Gill MIS, Kumar SR (2013) Effect of different levels of $\mathrm{N}$ and $\mathrm{P}$ on ratoon banana (Musa spp. AAA). J Hortic For. 5: 81-91.

Nomura ES, Cuquel FL, Damatto-Junior ER, Fuzitani EJ, Borges AL (2017) Fertilization with nitrogen and potassium in banana cultivars 'Grand Naine', 'FHIA 17' and 'Nanicão IAC 2001' cultivated in Ribeira Valley, São Paulo State, Brazil. Acta Sci Agron. 39: 505-513.

Novais SV, Novais RF, Alvarez VHV, Villani EMA, Zenero MDO (2016) Phosphorus-Zinc Interaction and Iron and Manganese Uptake in the Growth and Nutrition of Phalaenopsis (Orchidaceae). Rev Bras Cienc Solo. 40: 1-10.

Ova EA, Kutman UB, Ozturk L, Cakmak I (2015) High phosphorus supply reduced zinc concentration of wheat in native soil but not in autoclaved soil or nutrient solution. Plant and Soil. 393: 147-162.

Pereira LV, Silva SO, Alves EJ, Silva CRR (2003) Banana hybrids and cultivar evaluation in Lavras-MG. Cienc Agrotec. 27: 17-25.

Raij BV, Andrade JC, Cantarella H, Quaaggio JA (2001) Análise Química para Avaliação da Fertilidade de Solos Tropicais. Instituto Agronômico. Campinas, 285 p.

Ramaswamy N, Muthukrishnan CR (1974) Correlation studies in nutrition of Robusta banana. Indian J Hortic. 30: 145-147.

Robinson JC, Gálan-Saúco V (2011) Bananas y plantains. 2 edh. Mundi-Prensa, Madri. $321 \mathrm{p}$.

Shen J, Yuan L, Junling Z, Li H, Bai Z, Chen X, Zhang W, Zhang $F$ (2011) Phosphorus dynamics: from soil to plant. Plant Physiol. 156: 997-1005.
Silva JTA, Rodrigues MGV (2013) Production of 'Prata Anã' banana as affected by the application of phosphate fertilizer, in four cycles. Pesq Agrop Bras. 48: 613-618.

Silva SO, Flores JC, Lima Neto FP (2002) Evaluation of banana cultivars and hybrids in four production cycles. Pesq. Agrop. Bras. 37: 1567-1574.

Smith MK, Langdon PW, Pegg KG, Daniells JW (2014) Growth, yield and Fusarium wilt resistance of six FHIA tetraploid bananas (Musa spp.) grown in the Australian subtropics. Sci. Hortic. 170: 176-181.

Taiz L, Zeiger E, Møller IM, Murphy A (2017) Plant Physiology. 6 edh. Artmed, Porto Alegre, 888 p.

Teixeira LAJ, Nomura ES, Damatto-Junior ER, Fuzitani EJ (2014) Banana. In: Aguiar ATE, Gonçalves C, Paterniani MEAG, Tucci MGS, Castro CEF (Eds) Instruções agrícolas para as principais culturas econômicas. Instituto Agronômico, Campinas. 46-51.

Turner DW, Fortescue JA, Thomas DS (2007) Environmental physiology of the bananas (Musa spp.). Braz J Plant Physiol. 19: 463-484.

Zhang Z, Liao H, Lucas WJ (2014) Molecular mechanisms underlying phosphate sensing, signaling, and adaptation in plants. J Integr Plant Biol. 56: 192-220.

Zhao Z, Shi HJ, Wang ML, Cui L, Zhao H, Yun Z (2015) Effect of nitrogen and phosphorus deficiency on transcriptional regulation of genes encoding key enzymes of starch metabolism in duckweed (Landoltia punctata). Plant Physiol Bioch. 86: 72-81. 